\title{
ERGONOMIŠKOS DARBO VIETOS IR RAUMENŲ FIZIOLOGINIŲ POKYČIŲ SĄSAJOS MANIKIŪRO SPECIALISTO DARBE
}

\author{
Giedrè Bačkaitytė, Danguolė Grūnovienė \\ Kauno kolegijos Medicinos fakultetas
}

Raktažodžiai: ergonominès priemonès, fiziologiniai pokyčiai, ergonomiška darbo vieta.

\section{Santrauka}

Netaisyklingai sèdint bei būnant priverstinèje padètyje yra didelè tikimybė atsirasti rankų, kaklo, nugaros, kojų kaulų ir raumenų skausmui. Dirbant pritaikytomis, ergonomiškomis ir saugiomis sąlygomis, sukuriama optimali aplinka fizinei ir psichologinei sveikatai palaikyti. Svarbiausia detalè manikiūro specialisto darbe yra jo darbo kède, ant kurios sèdint darbingumas būtų išlaikomas kuo ilgesnị laiką ir nuovargis būtų minimaliausias. Kyla klausimas, kokia ergonominių priemonių taikymo svarba manikiūrininko darbe, kokie fiziologiniai pokyčiai vyksta raumenyse, atliekant manikiūrą ant paprastos ir ergonomiškos, balno formos kèdès? Šio tyrimo tikslas: ịvertinti ergonominès priemonès taikymo svarbą manikiūrininko darbe.

Tyrimo rezultatai rodo, jog kedès tipas, ant kurios sėdima, nedaro itakos trapeciniam, deltiniam ir priešpriešiniam rankos nykščio raumenims. Deguonies įsotinimas $\left(\mathrm{StO}_{2}\right)$ dilbio raumenyse kito priklausomai nuo to, ant kurios kèdès buvo sèdima. Sèdint ant balno formos kèdès $\mathrm{StO}_{2}$ kiekis statistiškai reikšmingai buvo padideję̨s nuo $75,5 \pm 0,7 \%$ iki $78,3 \pm 0,6 \% \mathrm{p}<0,05$. Didžiausias $\mathrm{StO}_{2}$ kiekis buvo sèdint ant balno formos kèdès, prieš manikiūrą buvo $92,4 \pm 0,4 \%$, po manikiūro - $92,8 \pm 0,5 \%$. Arterinè kraujotaka, rezervinè venų talpa, kraujo pritekejjimo greitis venose kito nereikšmingai. Pletizmogramos aukščio sumažejimas $(p<0,05)$ stebetas sèdint ant eksperimentinès balno formos kèdès. Eksperimento metu nustatyta, kad reikšmingiausias fiziologinis pokytis, sèdint ant balno formos kèdès $-\mathrm{StO}_{2}$ kiekio kaita. Sėdint ant šio tipo kẻdès ištiesiama nugara, laisviau funkcionuoja plaučiai, todèl stebimos didžiausios deguonies ịsotinimo reikšmès raumenyse. Kiti fiziologiniai pokyčiai: raumenų tonusas, klam- pa ir standumas, arterinè kraujotaka, rezervinè venų talpa, kraujo pritekejjimo greitis $\mathfrak{i}$ venas, pletizmogramos aukštis buvo statistiškai nepatikimi.

\section{Ivadas}

Manikiūro specialisto paslaugos tampa vis populiaresnès, jos dažnai atliekamos namuose, ịvairiuose kabinetuose, individualiai nepritaikytose darbo vietose, kas sąlygoja manikiūrininko procesinių ligų atsiradimą. Netaisyklinga, priverstinè kūno padètis manikiūrininkui gali sukelti rankų, kaklo, nugaros, kojų kaulų ir raumenų skausmus. Ergonomiška darbo vieta yra efektyvi prevencijos priemonè, sumažinanti tikimybę sutrikdyti grožio terapeuto darbą. Dirbant pritaikytomis ir saugiomis sąlygomis, sukuriama optimali aplinka fizinei ir psichologinei sveikatai palaikyti. Manikiūro specialisto darbas yra sėdimas, sédint - geresnè kraujo apytaka kojose, tačiau nekeičiama darbo poza. Darbo pozos kaita reguliuoja kūno audinių hidrostatinio spaudimo persiskirstymą, kuris pagerina žmogaus atramos - judamojo aparato kraujo apytaką, savijautą. Itin svarbi detalè manikiūro specialisto darbe yra jo darbo kèdè. Ją privalu išsirinkti patogią ir patikimą ergonominiu požiūriu, ant kurios sėdint, kuo ilgesnị laiką būtų išlaikomas darbingumas, o nuovargis būtų minimaliausias.

Ergonomika manikiūro specialisto darbe. Darbo poza - tai tam tikra kūno dalių padètis (rankų, kojų, blauzdų, dilbių ir kt.), atliekant sunkius darbus. Darbo pozos kaita reguliuoja kūno audinių hidrostatinio spaudimo persiskirstymą, kuris pagerina žmogaus atramos - judamojo aparato kraujo apytaką ir apskritai savijautą. Skiriamos dvi pagrindinès darbo pozos: stovima ir sédima.

Manikiūrininko darbas yra sèdimas. Pagrindinis šios darbo pozos privalumas - mažos energijos sąnaudos. Neigiamą įtaką manikiūrininkui turi ne tiek nepatogi poza, kiek laikas, kurị jis turi išbūti šioje pozoje. Sèdèti visą dieną nèra gerai fizinei būklei, ypač kenčia nugara. Todèl svarbu darbo vietą pritaikyti prie darbuotojų ūgio, įsigyti patogią ir šiam darbui pritaikytą kẻdę, turinčią leisti manikiūrininkui keisti kojų padètị. Manikiūrininkas, kuris 
išmano ergonomines darbo padètis, nuovargi darbo metu patiria vèliau. Anot mokslininkų Annetts ir kt. (2) atlikto tyrimo, patogiausios darbo kèdès yra balno formos. Ši kèdè palaiko taisyklingą sèdèseną bei saugo stuburą nuo perkrovos. A. Gandavadi ir kt. (2005) savo straipsnyje žurnale „Gydymas ir reabilitacija“ teigia, kad seddint ant balno formos kèdès dubuo yra palinkęs i priekį, viršutinè kūno dalis dirba produktyviau, sustiprinamos jos funkcijos. Sèdint dubenị palenkus ị priekį, skatinama sveikesnè manikiūrininko laikysena ir mažinamas stuburo diskų apkrovimas. Tačiau

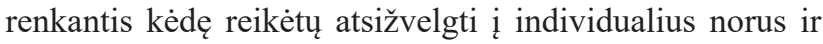
pojūčius.

Balno formos kèdè padeda išlaikyti tiesią sèdèseną bei sumažina juosmeninès nugaros dalies apkrovą. S. Guptos teigimu (8), sėdint ant balninès kèdès, kūno laikysena panaši i pusiau stovimą pozą dẻl gaunamo $135^{\circ}$ klubo kampo, taip sumažinamas palinkimas, kritimas ị priekị. Kojos darbu metu visuomet remiasi i grindis, todèl lengva pasukti kèdę reikiama kryptimi, pasiimti darbui reikalingus įrankius. Su šia kẻde judèti, ant jos atsisèsti ir nuo jos atsikelti yra paprasta ir greita. Kai nugara ištiesiama, laisviau funkcionuoja plaučiai, efektyviau panaudojami raumenys, nesédima vienoje pozoje, kas lètina medžiagų apykaitą ir sukelia nuolat naudojamų raumenų skausmą. O. Hokwerdos ir kt. nuomone (9), dèl didesnès galimybès judèti mažiau pavargstama ir ilgiau išsaugomas darbingumas.

Siekiant išsiaiškinti sėdèjimo ant skirtingų kèdžių poveikị kraujotakai, funkcinių raumenų įtempimui bei deguonies ịsotinimui buvo atliktas eksperimentinis tyrimas.

Tyrimo tikslas: atskleisti ergonomiškos darbo aplinkos ir raumenų fiziologinių pokyčių sąsajas manikiūro specialisto darbe.

\section{Tyrimo objektas ir metodai}

Tyrimo objektas - manikiūrininko, sėdinčio ant paprastos ir ergonomiškos kèdès, fiziologiniai raumenų pokyčiai darbo metu.

Tyrimo metodai: mokslinès literatūros analizė; veninè okliuzinè pletizmografija; miotonometrija; neinvazinè artimoji infraraudonoji spektroskopija; statistiné duomenu analizè.

Tyrimas atliktas Kaune LSU Kineziologijos laboratorijoje, $2016 \mathrm{~m}$. balandžio-gegužès mènesiais. Tyrime dalyvavo penkios 22-24 metų merginos, kurių atrankos kriterijai: labai panašūs ūgiai ir svoriai; minimali manikiūro procedūru atlikimo patirtis; tyrimo metu nebuvo taikyta poveikio priemonès; tiriamosios atliko tą pačią tyrimo eigą (dalyvavo keturiuose eksperimento etapuose): atliko du kontrolinius ir du eksperimentinius tyrimus - manikiūro procedūras, sėdint ant skirtingų formų kẻdžių - paprastos ir ergonomiškos, balno formos kèdès. Vienos simuliacijos trukmè po 30 minučių.

Venų okliuzinė pletizmografija. Eksperimento metu atlikta arterinès kraujotakos registracija veninès okliuzinès pletizmografijos metodu. Tyrimo proceso metu naudota nupjauto kūgio formos, $15 \mathrm{~cm}$ pločio proksimalinè manžetè, ji buvo dedama ant šlaunies. Tokios formos manžete gerai priglunda prie galūnès ir beveik nesukelia okliuzinio artefakto. Distalinès manžetès plotis $-10 \mathrm{~cm}$. Oras ị manžetes pripučiamas labai greitai - ne ilgiau kaip per 0,5 sekundès. Oras iš manžečiu buvo išleidžiamas i vakuumo rezervuarą.

Venų okliuzinè pletizmografija - vienas iš tiksliausių periferinès kraujotakos registravimo metodų. Šiuo metodu registruojami periferinès kraujotakos rodikliai, lyginant su invaziniais metodais, skiriasi tik iki 5 proc. Okliudavus venas proksimaliaja manžete, kuri yra virš tiriamo segmento, per pirmąsias kelias sekundes padidejja tiriamo segmento apimtis. Śis padidejimas yra tiesiogiai proporcingas arterinio pritekejjimo greičiui, kadangi per tokị trumpą laiko tarpą slègis venose ir arterijose nekinta dèl veninių kraujagyslių tamprumo. Tiriamo segmento apimties padidejimas po venų okliuzijos rodo arterinio kraujo kiekį, kuris buvo prieš venų okliuziją.

Miotonometrija. Naudojant elektromiografijos metodą, miotonometru išmatuojami nervinių impulsų, pasiekiančių raumenis, parametrai. Jie atspindi raumenų būkles, kurios nusako darbingumo atsistatymą darbo metu ir po jo bei mechaninès ịtampos perdavimą i kaulus. Miotonometras - originalus prietaisas, naudojamas raumenų pasyviujų mechaninių savybių: klampumo, tonuso, standumo matavimams atlikti.

Atliekant miometrinius matavimus tiriami šie parametrai:

Osciliacijos dažnis - charakterizuoja raumens įtampą. Raumenų, esančių funkcinès relaksacijos būklèje, natūralios osciliacijos dažnis charakterizuoja jų tonusą. Raumenų, esančių funkcinès kontrakcijos būklèje, natūralios osciliacijos dažnis apibūdina raumens jègą. Priklausomai nuo raumens šio parametro reikšmės svyruoja nuo $18 \mathrm{iki} 40 \mathrm{~Hz}$. Normoje relaksuoto raumens įtampa yra maža, raumeniui susitraukus ji padidejja. Tais atvejais, kai nestebima žymaus skirtumo tarp relaksuoto ir susitraukusio raumens osciliacijos dažnio, normalus raumenų funkcionavimas gali būti rimtai sutrikęs.

Raumenu slopinimas - charakterizuoja raumens elastingumą, t.y. raumens gebejjimą atstatyti pirminę formą po susitraukimo. Dekrementas nustatomas stebint, ar greitai užgęsta svyravimas. Slopinimo vertès, apskaičiuotos remiantis tyrimų rezultatais, paprastai nebūna didesnès nei $1,0-1,2$, priklausomai nuo raumens. Kai raumenys treniruo- 
ti susitraukusių raumenų slopinimas mažèja (pvz.: nuo 1,0 iki 0,6), tuo būdu stebimas raumens elastingumo didejjimas. Virpesių slopinimo logaritminis dekrementas skaičiuojamas pagal formulę:

$$
\theta=\ln \frac{a_{3}}{a_{1}}
$$

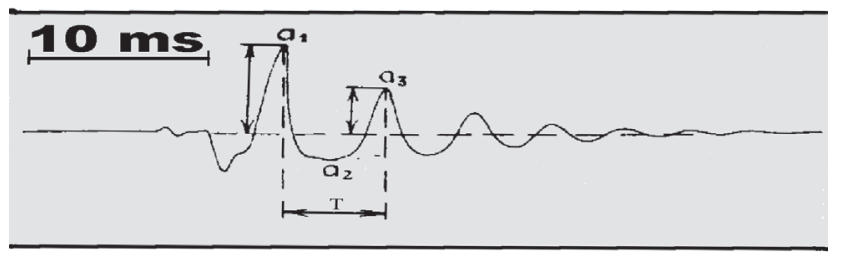

1 pav. Atpalaiduoto raumens elektromiotonograma (Vain, 1995)

Raumenų tamprumas - charakterizuoja raumenų sugebejjimą išlaikyti formos pokyčius, sukeltus išoriniu veiksnių. Tamprumo reikšmès labai priklauso nuo tiriamų raumenų, paprastai jis būna nuo $150-300 \mathrm{~N} / \mathrm{m}$ ribose. Susitraukus raumenims tamprumo reikšmès gali būti didesnès nei $1000 \mathrm{~N} / \mathrm{m}$. Nẻra tikslių normų įvairiems žmonèms, taigi norma reikètų laikyti tuos parametrus, kurie būdingi sveikam žmogui.

Raumens gebėjimas priešintis raumenị deformuojančiai jègai vadinamas raumens standumu. Padidejus raumens standumui reikia daugiau jègos įtempti antagonistus. Tai padidina energijos sunaudojimą atliekant judesius $(7,1)$.

Kiekviena kieta medžiaga pasižymi klampa (plastiškumu) ir tamprumu (elastiškumu). Klampa - raumenų vidiné trintis. Kuo didesnè klampa, tuo mažesnis elastingumas, ir

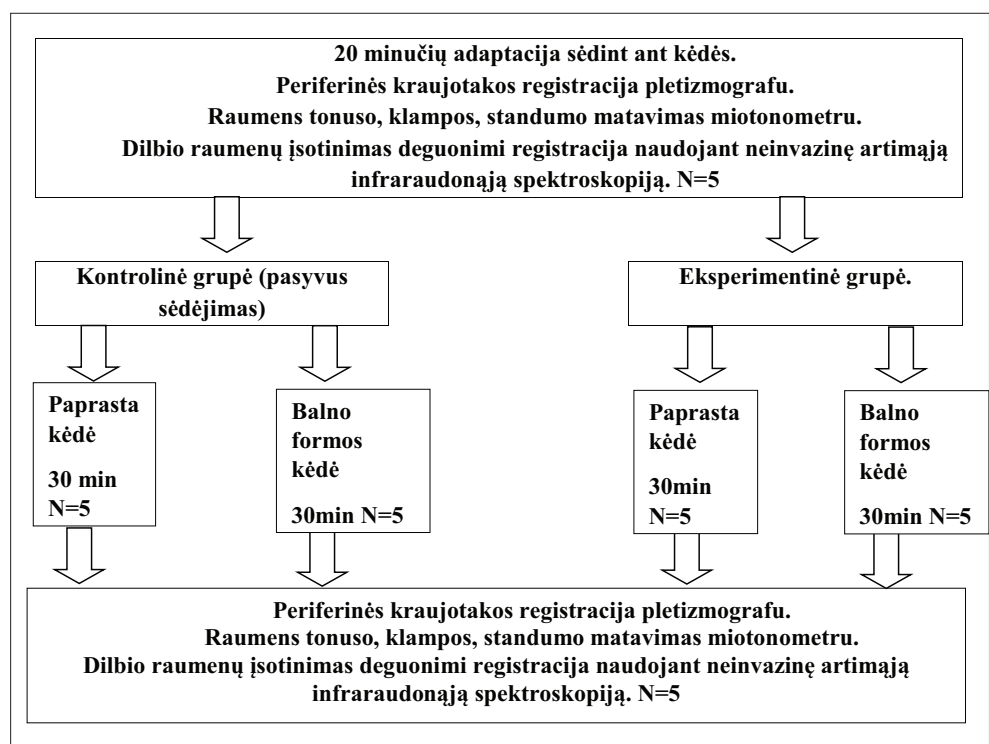

2 pav. Tyrimo organizavimo ir atlikimo protokolas atvirkščiai. Bet kuri trintis sukelia energijos nuostolius, todèl visada daugiau ar mažiau trintis slopina mechaninius virpesius. Laisvųju virpesių gesimo spartumą apibūdina virpesių logaritminis dekrementas. Raumens elastingumas (dekrementas) nusako raumens gebejjimą atgauti savo pradinę formą po susitraukimo ar nustojus veikti deformuojančiai išorès jègai. Kai elastingumas mažèja (dekrementas didèja), raumens veikla yra sutrikdoma ir padidejja raumens patologijos rizika (7).

Raumenų pasyviosios mechaninès savybès vertintos naudojant prietaisą „MYOTON-3“. Prietaiso veikimas paremtas sukeltų gęstančiu raumens virpesių matavimu ir analize. Matavimai atlikti sédimoje padètyje (atpalaidavus ir įtempus raumenį). Prieš tyrimą ant raumenų buvo pažymimi taškai, matavimai atliekami tris kartus toje pačioje vietoje, skaičiavimams naudoti rodmenų vidurkiai.

Duomenų analizei naudotas programinis paketas MS Offise EXCEL 2013. Vertintas aritmetinis vidurkis \pm standartine paklaida. Rezultatu patikimumas vertintas taikant Stjudent'o t kriterijų.

Neinvazinė artimoji infraraudonoji spektroskopija. Vietiniam raumenų oksigenacijos metabolizmui įvertinti poilsio ir skirtingų fizinių krūvių metu nuo 1980-ujų metų naudojama neinvaziné artimoji infraraudonoji spektroskopija. Artimo infraraudoniesiems spinduliams diapazono spektroskopijos metodas (NAIS) yra neinvazinis, nežalingas audiniams ir suteikia daug informacijos apie giliujų audinių kraujotaką bei deguonies ịsotinimą realiu tyrimo laiku. Veikiant NAIS šviesos spektrui, pirminės šviesą absorbuojančios molekulès audiniuose yra metalo komplekso chromoforai: hemoglobinas $(\mathrm{Hb})$, bilirubinas ir citochromai. NAIS prietaisuose naudojama tokio bangos ilgio šviesa, kuriai biologiniai audinių chromoforai yra jautriausi. NAIS matavimo duomenims turi ịtakos heterogenine audinio struktūra, kuri priklauso nuo kapiliarų, arterijų, venų tinklo ir kitų, nekraujagyslinių, audinio struktūrų. Hemoglobinas yra pagrindinis NAIS šviesą absorbuojantis chromoforas.

Kraujo pritekejimas ị audinius, kraujo ịsotinimas deguonimi ir oksidacinis mechanizmai yra svarbūs kriterijai širdies kraujagyslių sistemos ligoms bei ịvairiems ląsteliniams sutrikimams nustatyti. Artimo infraraudoniesiems spinduliams diapazono spektroskopijos metodo metu panaudojamas žemos absorbcijos spektras audinyje, artimas infraraudonųjų spindulių spektrui (650-9502m), kuris issiskverbia giliai i audini (apie kelis cm), tikslu aptikti oksi- ir deoksi-hemoglobiną $\left(\mathrm{HbO}_{2}\right.$ ir $\left.\mathrm{Hb}\right)$. Šis meto- 
das yra svarbus, ịvertinant kraujo pritekejimo santykini pokyti giliuosiuose audinių sluoksniuose bei deguonies metabolizmą audiniuose.

Dilbio raumenų hemodinaminiai rodikliai vertinti neinvaziniu artimosios infraraudonosios spektroskopijos būdu, naudojant fotojutiklį. Fotojutiklis tvirtintas ant dilbio, šalia alkūnès. Taip matuotos visos tiriamosios, užregistruotas deguonies įsotinimas $\left(\mathrm{StO}_{2}\right)$, kontrolinèje bei eksperimentinèje grupèse, prieš simuliacinị manikiūrą ir po jo. Deguonies įsotinimas $\mathrm{StO}_{2}$ registruotas prieš pradedant kiekvieną simuliaciją ir po 30 minučių darbo arba pasyvaus sėdejjimo.

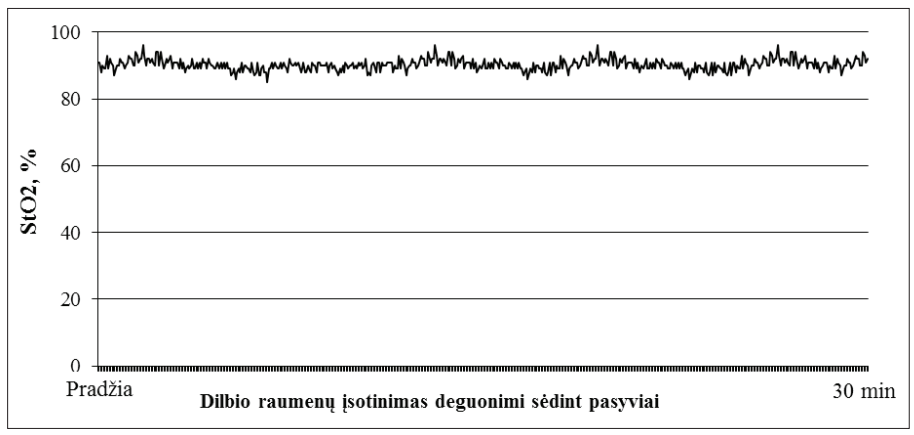

3 pav. Dilbio raumenų deguonies įsotinimo kaita sėdint pasyviai. $(\mathrm{N}=1)$

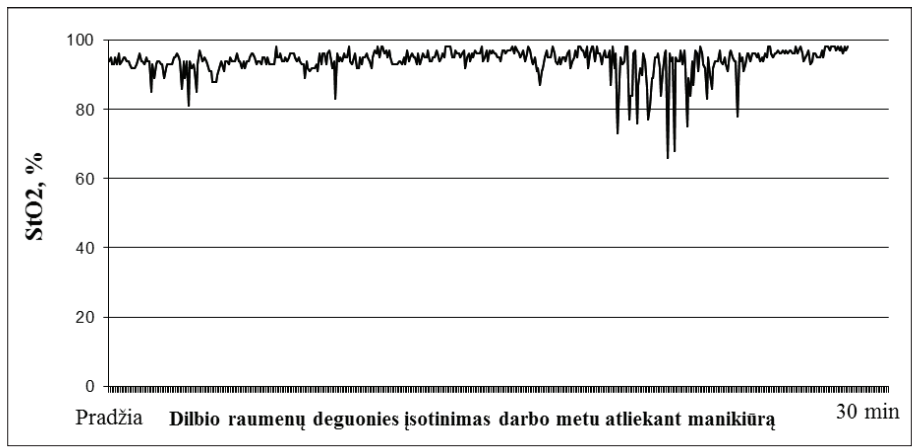

4 pav. Dilbio raumenų deguonies ịsotinimo kaita atliekant manikiūrą $(\mathrm{N}=1$

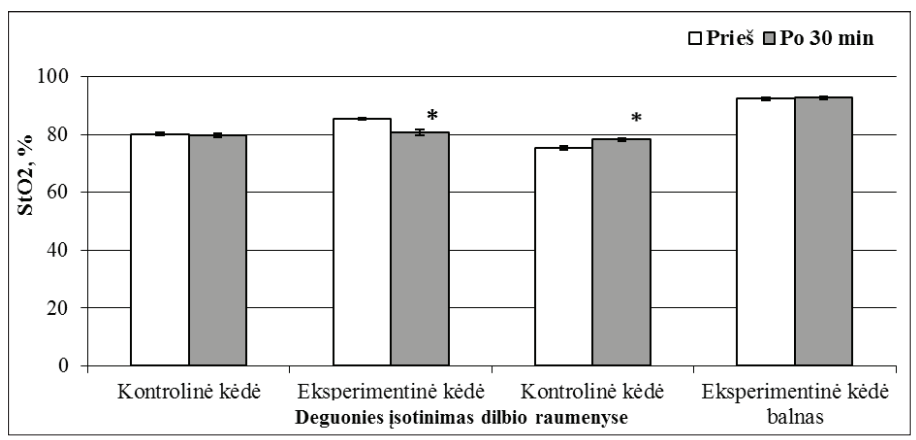

5 pav. Deguonies įsotinimo kaita kontrolinèse ir eksperimentinėse grupèse dilbio raumenyse. $(\mathrm{N}=5) *<0.05$
Tyrimo organizavimas ir eiga. Kiekvieną kartą, prieš pradedant tyrimą, visos penkios tiriamosios atlikdavo 20 minučių adaptaciją sédint. Po adaptacijos buvo žymimi taškai ant raumenų (trapecinio, deltinio ir priešpriešinio rankos nykščio), kur prieš ir po tyrimo atliekamas raumens tonuso, klampos ir standumo matavimas miotonometru atpalaidavus ir įtempus raumenic. Kiekviename taške atlikti 3 matavimai, kurių duomenų vidurkiai užrašyti lentelèje. Uždejjus venų okliuzinès pletizmografijos manžetes, ramybès būsenoje buvo užrašoma pletizmograma. Ant dilbio uždètas NAIS fotojutiklis viso tyrimo metu, nepertraukiamai matavo deguonies ịsotinimą dilbio raumenyse. Po atliktų matavimų miotonometru ir užrašius pletizmogramą, kontrolinių tyrimų metu, tiriamosios 30 minučių sèdejjo pasyviai, o eksperimentinių tyrimų metu - 30 minučių atliko manikiūrą. Darytas tik saugus manikiūras, naudojant vienkartinius įrankius, nekarpant odelių. Stalviršiai prieš procedūrą buvo dezinfekuojami, atliekama tiriamosios ir klientès, kuriai daromas manikiūras, rankų antiseptika. Po 30 minučių vèl atliekami matavimai miotonometru ir užrašoma pletizmograma.

Tyrimas buvo atliktas pagal iš anksto sudarytą eksperimento atlikimo protokolą (2 pav.)

Statistinė duomenų analizė. Gauti atlikto tyrimo rezultatai buvo apdoroti duomenų analizès programa Microsoft Excel 2013“. Skaičiuoti gautų tyrimo rodiklių aritmetiniai vidurkiai, standartiniai nuokrypiai, vidurkių skirtumų reikšmingumui apskaičiuoti, Stjudent'o t kriterijų priklausomoms imtims. Pasirinktas reikšmingumo žymèjimas $\mathrm{p}<0,05$ (reikšminga).

Etiniai tyrimo aspektai. Eksperimentinio tyrimo dalyvės sutiko dalyvauti savo noru, buvo gautas jų žodinis sutikimas. Tiriamosioms buvo užtikrintas jų anonimiškumas, informacijos konfidencialumas, buvo pranešta, kad tyrimo duomenys bus pristatomi apibendrintai, neminint konkrečių vardų ar pavardžių. Tyrimo dalyvėms buvo suteikta informacija apie tyrimą, nurodant tyrimo tikslą, eigą, tyrèjo funkcijas, galimybę susipažinti su tyrimo rezultatais.

Tyrimo „Ergonomiškos darbo vietos ir raumenų fiziologinių pokyčių sąsajos manikiūro specialisto darbe" rezultatai. Kontrolinès ir eksperimentinès grupių, sẻdint ant skirtingų tipų kẻdžių, raumenų funkcinė būsena buvo nustatoma trimis rodikliais: tonusu, standumu ir klampa. Raumenų tonusas apibrèžiamas kaip atpalaiduotų raumenų mechaninis įtempimas, kurio negalima sumažinti valios pastangomis. Raumenų tonusas gali būti ịvertinamas ịvairias bū- 
dais, objektyviausiai jis nustatomas naudojant instrumentinius tyrimo metodus.

Osciliacijos dažnis ramybès būsenoje apibūdina raumenų tonusą, kontrakcijos būsenoje - raumens jègą. Gautais duomenimis, visų tirtujų (trapecinio, deltinio ir priešpriešinio rankos nykščio) raumenu rodmenys nebuvo statistiškai patikimi ir kito nereikšmingai. Nei kontrolinèje, nei eksperimentinèje grupèse, sèdint ant paprastos ir ant balno formos kèdès, reikšmingi pokyčiai nebuvo pastebėti.

Gauti rezultatai rodo, kad raumenu mechaninè savybė - klampa - kito nevienareikšmiškai. Trapecinis ir deltinis raumenys buvo analogiško dydžio, jų dekrementas neženkliai kito. Ženklus rezultatų skirtumas kontrolinèje ir eksperimentinejje grupèse buvo pastebètas atpalaidavus ir ịtempus priešpriešinį rankos nykščio raumeni nepriklausomai nuo to, ant kokios kèdès buvo sèdima.

Tirtujų raumenų standumas eksperimentinèse grupėse kito nereikšmingai, buvo analogiško dydžio kaip ir kontrolinėse grupèse. Didžiausias reikšmių skirtumas buvo tarp atpalaiduoto ir įtempto priešpriešinio rankos nykščio raumens. Atpalaiduoto raumens tamprumas $271,2 \pm 19,8 \mathrm{~N} / \mathrm{m}$, o itempto siekia $593 \pm 83,19 \mathrm{~N} / \mathrm{m}$. šie duomenys rodo raumens treniruotumą, bet ne priklausomybę nuo to, ant kurios kèdès sèdima.

Bet koks mechaninis dirgiklis sukelia raumens susitraukimą, kuris intensyvina kraujotaką. Arterinès kraujotakos atsakas dilbyje 3 minučių trukmès izometriniame režime padidina kraujotaką nuo $2,5 \mathrm{ml} / 100 \mathrm{ml} / \mathrm{min}$. padidèja iki $5 \mathrm{ml} / 100 \mathrm{ml} / \mathrm{min}$. Atliekant manikiūrą keleto raumenų darbo trukmé izometriniu režimu nebūna ilgesnè kaip 30 sekundžių, tai mažo intensyvumo fizinis krūvis. NAIS metodas rodo (deguonies įsotinimą) kraujotakos intensyvumo kaitą priklausomai nuo išorinio dirgiklio dydžio. Kraujotakos intensyvumas labiau priklauso nuo fizinio krūvio intensyvumo negu nuo apimties. Tai rodo kaip oksigenacijos padidejimą paveikia didesnis dirgiklis (3, 4 pav.).

Deguonies ịsotinimo kaita dilbio raumenyse priklauso nuo tiriamosios atliekamų veiksmų ir judesių. Kontrolineje grupeje, sèdint pasyviai ir neatliekant jokių veiksmų, $\mathrm{StO}_{2}$ kito neženkliai. Eksperimentinejje grupejje, atliekant manikiūrą, kiekvienas rankos sugniaužimas, raumens įtempimas mažina $\mathrm{StO}_{2}$ kieki raumenyje. Aktyviausi dilbio raumenu judesiai stebimi 22-26 minutę, jie $\mathrm{StO}_{2}$ kiekị sumažino iki 66\%. Baigus darbą deguonies įsotinimas di-

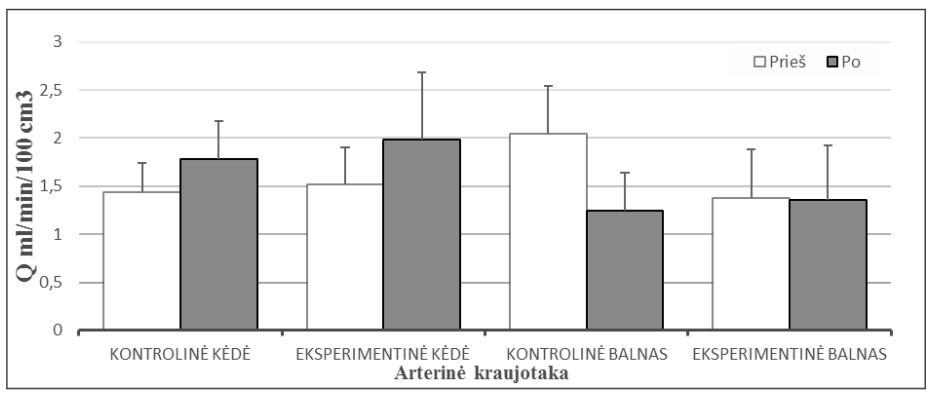

6 pav. Arterinès kraujotakos kaita kontrolinėse ir eksperimentinėse grupèse $(\mathrm{N}=5)$

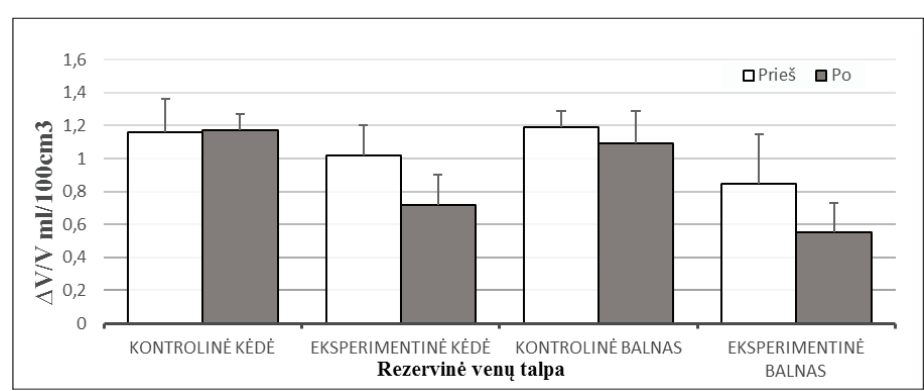

7 pav. Rezervinès venų talpos kaita kontrolinėse ir eksperimentinėse grupèse $(\mathrm{N}=5)$

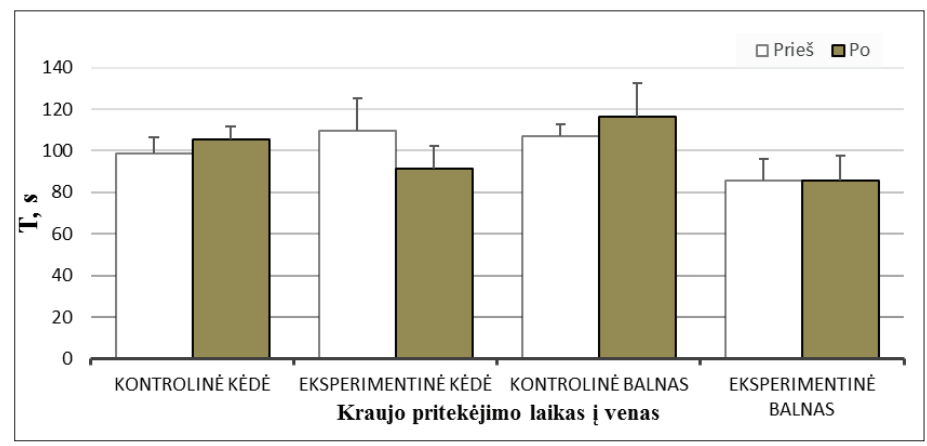

8 pav. Kraujo pritekejjimo laikas ị venas kontrolinėse ir eksperimentinėse grupèse $(\mathrm{N}=5)$.

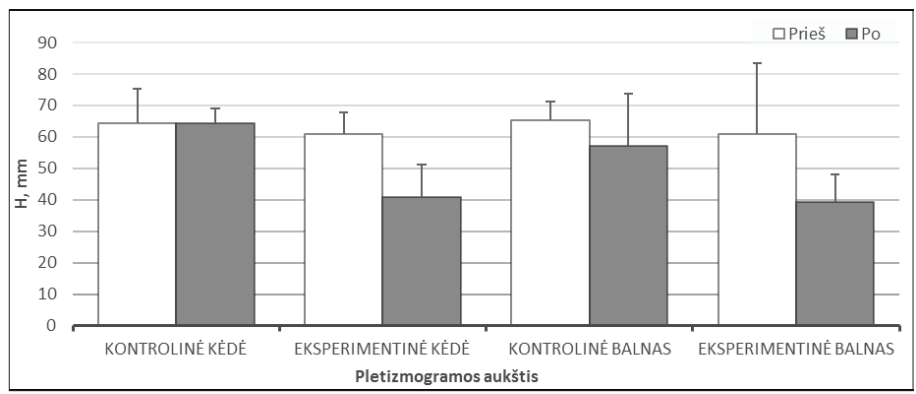

9 pav. Pletizmogramos aukštis kontrolinėse ir eksperimentinėse grupėse $(\mathrm{N}=5)$ 
dejjo, ir buvo didesnis $4 \%$ nei prieš pradedant darbą (4 pav.).

Deguonies ísotinimas dilbio raumenyse kontrolinèse grupèse kito skirtingai. Sèdint ant paprastos kèdès po procedūros deguonies ịsotinimas sumažèjęs nežymiai, o sẻdint ant balno formos kèdès statistiškai reikšmingai buvo padidejęs nuo 75,5 $\pm 0,7 \%$ iki 78,3 $\pm 0,6 \% \mathrm{p}<0,05$. Eksperimentinèje grupeje sèdint ant paprastos kèdès rezultatai skyrèsi ženkliai, po procedūros deguonies įsotinimas buvo statistiškai reikšmingai sumažèjęs nuo $85,4 \pm 0,4 \%$, iki $80,8 \pm 1 \%$. Sèdint ant balno formos kèdès eksperimentinèje grupeje $\mathrm{StO}_{2}$ reikšmès prieš, po procedūros nesiskyrè, tačiau buvo maksimaliai didžiausios iš visų grupių. Prieš manikiūrą $\mathrm{StO}_{2}$ buvo $92,4 \pm 0,4 \%$, po manikiūro pasiekè $92,8 \pm 0,5 \%$ (5 pav.).

M. Raitakari su bendraautoriais (1996) teigia, kad žmogaus raumenimis ramybès būsenoje teka $1,1-7,5 \mathrm{ml} /$ $\mathrm{min} / 100 \mathrm{ml}$ kraujo. Manoma, kad tokie dideli individualūs raumenų kraujotakos skirtumai ramybès sąlygomis gali būti prieš tai vykusio darbo liekamasis efektas. Nuo raumenų kraujotakos kaitos priklauso deguonies suvartojimo intensyvumas. Raumenų perfuzija ramybės sąlygomis gana maža, pratimo metu ji padidejja, atitinkamai atliekamo pratimo intensyvumui. Lokalioji kraujotaka intensyvejja dèl centrinių kontrolès mechanizmų, rezistyvinių (pasipriešinimas) kraujagyslių, lokaliosios vazodilatacijos (išsiplètimas lokalus) ir mechaninių raumens susitraukimų. Šio eksperimento metu atliktame tyrime gauti arterinès kraujotakos rezultatai buvo analogiškų dydžių. Mažiausias arterinès kraujotakos intensyvumas sudare $1,24 \pm 0,4 \mathrm{ml}$, o didžiausias 2,04 $\pm 0,5 \mathrm{ml}$. Tyrimo metu gautus dydžius palyginus su mokslinès literatūros duomenimis, rezultatų sklaida nèra didelè. Nedidelè minimalių ir maksimalių rezultatų reikšmių sklaida rodo, kad kraujotaka dèl menkų mechaninių raumens susitraukimų mažai kinta.

Arterinės kraujotakos intensyvumas kontrolinèje grupejje sèdint ant kẻdès, prieš tyrimą ir po jo, buvo analogiškų dydžių kaip eksperimentinejje grupejje sèdint ant kèdès. Sèdint ant kèdès balno kontrolinèje grupejje arterinè kraujotaka buvo neženkliai didesnè nei eksperimentinèje grupejje sédint ant kèdès balno. Arterinès kraujotakos intensyvumas kontrolinėje grupejje sédint ant kèdès po 30 minučių tyrimo turi tendenciją didèti, o eksperimentinejje grupeje sèdint ant kèdès balno turi tendenciją mažèti. (7 pav.)

Rezervinè venų talpa kontrolinejje grupejje ( 7 pav.) sèdint ant paprastos kèdès buvo $1,16 \pm 0,2 \mathrm{ml} / 100 \mathrm{~cm}^{3}$, po 30 minučių sèdejjimo ramybès būsenoje rezervinè venų talpa neženkliai kito. Eksperimentinejje grupejje, sèdint ant paprastos kèdès, rezervinès venų talpos skirtumas prieš ir po darbinès veiklos siekia $0,3 \mathrm{ml} / 100 \mathrm{~cm}^{3}$, analogiški rezervinès venų talpos dydžiai buvo stebimi ir sèdint ant eks- perimentinès kėdės balno. Po 30 minučių tyrimo rezervinè venų talpa kai kuriais atvejais turi tendenciją mažèti. Tai rodo, kad sėdint ilgą laiką, nepriklausomai nuo to, ant kokios kèdès tiriamosios sèdèjo, rezervinès venų talpos mažèjo, vadinasi, jos buvo pripildytos krauju. Tai galima spręsti iš venų pritekejjimo greičio trukmès. (8 pav.) Kraujo pritekejjimo ir ištekèjimo pusiausvyra (venų talpos prisipildymo greitis) kinta nevienareikšmiškai. Sèdint ant paprastos kèdès eksperimentinèje grupeje, venu pritekèjimo greitis sumažèjo. Sėdint ant eksperimentinès kèdès balno kraujo pritekejjimo greitis liko toks pats, kitais atvejais didejo.

Pletizmogramos aukštis (9 pav.) susijęs su rezervine venų talpa (7 pav.), žinoma, ir su pritekejjimo trukme ( 8 pav.). Pletizmogramos aukštis rodo venų rezervines galimybes, prisipildymą. Tai priklauso nuo venų tonuso. Esant dideliam pletizmogramos aukščiui, galima spręsti apie venų atituštinimą. Tačiau dar tam ịtakos turi slègis manžetėje. Jeigu slègis manžetèje yra didelis, tuomet pletizmogramos aukštis gali parodyti rezervinių venų talpų didejjimą. Sédint ant kẻdès kontrolinèje grupejje pletizmogramos aukštis nekito, kitais atvejais turèjo tendenciją mažèti. Sejdint ant balno formos kèdès gauname statistiškai reikšmingą sumažejimą $p<0,05$. Pletizmogramos aukščio sumažejimas parodo, kad venos užpildytos krauju.

Po tyrimo apklausus tiriamąsias buvo išsiaiškinta jų subjektyvi nuomonė apie darbo kokybę ir pojūčius sédint ant paprastos ir ergonomiškos kèdès. Diskomfortą apatinèje nugaros dalyje, sédint ant paprastos kèdès, jaute $60 \%$ tiriamujų, o ant balno formos kèdès - 40\%. 80\% tiriamujų teige, kad, sèdint ant ergonomiškos balno formos kèdès, randama patogesnè kojų padètis, lengviau judèti ir prisitaikyti prie darbo vietos. $80 \%$ tolimesniam darbui rinktųsi balno formos kèdę, nes mano, kad ant jos sèdèti yra saugiau. Visos tiriamosios sutiko, kad iš pradžių sèdèti ant balno formos kèdès yra keista ir nepatogu, nes yra neịprastas kèdès tipas ir dirbama sèdint netaisyklinga poza, bet mano, jog ipratus sẻdèti galima išlaikyti ilgesnį darbingumą. Siūloma eksperimentą tęsti.

\section{Išvados}

1. Ergonominiai rizikos veiksniai: netaisyklinga darbo poza, ilgai trunkantis stovèjimas arba sejdejjimas sulenktomis kojomis, monotoniški riešo judesiai sukelia profesinius sveikatos sutrikimus. Ergonomiška darbo vieta yra efektyvi prevencijos priemonè, daranti įtaką optimaliam žmogaus funkcionavimui, geram darbingumui, minimaliam nuovargiui ir monotonijai, kokybiškiems darbo rezultatams, pasitenkinimui darbu ir santykiais jame. Dirbant pritaikytomis ir saugiomis sąlygomis, sukuriama optimali aplinka fizinei ir psichologinei sveikatai palaikyti. Ergonomika manikiū- 
rininko darbe: darbo vietos ịrengimas, darbo poza, horizontali darbo zona, darbinis aukštis, regejjimo atstumas.

2. Reikšmingiausias fiziologinis pokytis, sėdint ant ergonomiškos balno formos kèdès - $\mathrm{StO}_{2}$ kiekio kaita. Sédint ant šio tipo kèdès, ištiesiama nugara, laisviau funkcionuoja plaučiai, todèl stebimos didžiausios deguonies įsotinimo reikšmès raumenyse. Kiti fiziologiniai pokyčiai: raumenų tonusas, klampa ir standumas, arterine kraujotaka, rezervinè venų talpa, kraujo pritekèjimo greitis ị venas, pletizmogramos aukštis buvo statistiškai nepatikimi.

\section{Literatūra}

1. Aarrestad DD, Williams MD, Fehrer SC, Mikhailenok E, \& Leonard CT. Intra-and interrater reliabilities of the myotonometer when assessing the spastic condition of children with cerebral palsy. [interaktyvus] Journal of child neurology 2004; 19(11): 894-901.

2. Annetts S, Coales P, Colville R, Mistry D, Moles K, Thomas B, \& van Deursen RA. Pilot investigation into the effects of different office chairs on spinal angles. [interaktyvus] European Spine Journal, 2012; 21(Suppl 2): 165-170. [žiūrèta 2015-12-03] Prieiga per internetą: http://doi.org/10.1007/s00586-012-2189-z .

3. Bachoura A, \& Jacoby SM. Ulnar tunnel syndrome. [interaktyvus] Orthopedic Clinics of North America 2012; 43(4):467-474. https:/doi.org/10.1016/j.ocl.2012.07.016

4. Chuang LL, Lin KC, Wu CY, Chang CW, Chen HC, Yin HP, \& Wang, L. Relative and absolute reliabilities of the myotonometric measurements of hemiparetic arms in patients with stroke, 2013.

5. Čyras P., Girnius V., Kaminskas K.A. Profesinè sauga ir sveikata. Ergonomikos principai, Vilnius, 2003.

6. Gandavadi A, \& Ramsay J Effect of two seating positions on upper limb function in normal subjects. [interaktyvus] Int J Ther Rehabil 2005; 12(11): 485-490. [žiūrèta 2016-02-22] Prieiga per internetą: https://www.researchgate.net/publication/272529578_Effect_of_two_seating_positions_on_upper_limb_function_in_normal_subjects.

7. Gapeyeva H, Vain A. Methodical guide: principles of applying Myoton in physical medicine and rehabilitation. Müomeetria Ltd, Tartu, Estonia, 2008.

8. Gupta S. Ergonomic applications to dental practice. Indian journal of dental Research 2011; 22(6): 816.

https:/doi.org/10.4103/0970-9290.94677

9. Hokwerda OO, Wouters J J, \& de Ruijter RR. Ergonomic requirements for dental equipment. Guidelines and recommendations for designing, constructing and selecting dental equipment, 2006.

10. Salvendy G. Handbook of Human Factors and Ergonomics. John Wiley \& Sons: Canada, 2012.

https:/doi.org/10.1002/9781118131350

11. Ramonas Z., Čikotienė D. Ergonomika. Žmonių saugos pagrindai. Šiauliai, 2009.

\section{RELATIONS BETWEEN ERGONOMIC WORKPLACE AND PHYSIOLOGICAL MUSCLE ALTERATIONS IN MANICURE SPECIALIST'S WORK G. Bačkaitytė, D. Grūnovienė}

Key words: ergonomic equipment, physiological change. Summary

The relevance of the thesis. The inappropriate posture of work and wrong sitting pose are the two main reasons which can cause the musculoskeletal pain in arms, neck, back and legs. Whereas, working in favorable, ergonomic and safe conditions creates an optimal environment for the physical and psychological health to maintain. The most important equipment in manicurist's work is a work chair. The work chair must ensure productive work for a longer period of time and to maintain the level of fatigue at the minimum level.

The objective of the thesis is to evaluate the importance and the usage of ergonomic equipment at manicurist's work.

The tasks of the research:

1. To describe ergonomic factors, equipment and to present the possible occupational diseases for manicurist.

2. To measure the physiological changes of muscles during the manicure procedures on the simple and the saddle chairs.

The methods and research. The study included five 21-24 yearold girls that participated twice in the control group and twice in the experimental group, sitting on a simple and ergonomic chairs. In the research the myotonometer was used and the methods of spectroscopy and plethysmography were applied.

The results. The type of the chair does not affect trapezoidal, deltoid and flexor digitorum longus in the thumb. The saturation of the oxygen $\left(\mathrm{StO}_{2}\right)$ in the forearm muscles depended on which chair the participant of the research sit. The sitting on a saddle chairs increased $\mathrm{StO} 2$ from $75.5 \pm 0.7 \%$ to $78.3 \pm 0.6 \%, \mathrm{p}<0.05$. The greatest amount of $\mathrm{StO}_{2}$ was observed when the participant was sitting on saddle chair. Before the manicure $\mathrm{StO}_{2}$ was $92.4 \pm$ $0.4 \%$ and after a manicure $-92.8 \pm 0.5 \%$. The arterial blood supply, the capacity of venous and the speed of blood flow in the veins changed insignificantly. The reduction of plethysmography height $(p<0.05)$ was observed when the participant was sitting on the experimental saddle chair.

The conclusions of the thesis:

1. An ergonomic workplace is an effective and at the same time a preventive tool which might affect optimal functioning of the person. Also, the ergonomic workplace can influence performance at work and help to avoid fatigue and monotony. Moreover, it might increase the satisfaction in job and improve relationships with colleagues as well. Favorable working and safety conditions create an optimal environment for the physical and psychological health to maintain.

2. The experiment showed that the most significant physiological change, while sitting on the saddle chair is the change of $\mathrm{StO}_{2}$. When sitting on this type of chair back is straight and due to this lungs can function better. This affects the saturation of oxygen in the muscles. The other physiological changes in muscle tone such as viscosity and stiffness, arterial blood, volume of venous reserve, velocity of blood flow in the veins and the height of plethysmography were statistically uncertain.

Correspondence to: danguole.grunoviene@go.kauko.lt

Gauta 2016-11-10 